\title{
The Possibility or Impossibility of Islamization of Knowledge in a Neoliberal Market Order
}

\author{
Omar Javaid ${ }^{1 *}$, Wahab Suri ${ }^{2}$ \\ ${ }^{1}$ Institute of Business Management, Karachi, Pakistan \\ ${ }^{2}$ Philosophy Department, Karachi University, Pakistan
}

\section{Keywords}

Islamization of Knowledge

Power-Knowledge Nexus

Political Economy

Epistemological Antagonism

Division of labor

Received: 07 January 2019

Accepted: 17 March 2020

\begin{abstract}
This paper argues that the project of the Islamization of Knowledge (IoK) has overlooked the role of a neoliberal politicoeconomic order in the knowledge production along with the relation between knowledge and the market established by economic liberalization. So the resulting discourse perhaps inadequately explains the incapacity of contemporary application of Islamic economics and finance to provide a viable alternative to western economic systems, let alone solve socioeconomic problems in Muslim countries. This paper will attempt to cover this inadequacy by explaining the relation between mind, knowledge and market as theorized by Hayek, along with Foucault's perspective power-knowledge nexus. The Hayek's and Foucault's perspective on the relation between state, market, mind and knowledge creates an interesting challenge for IoK because it is not only the issue of reconciliation of the spheres of knowledge, rather free unhampered flow of market is also presumably necessary for the growth of human mind and consequently human knowledge as argued by Hayek and Foucault. The neoliberal-state allows free unhampered flow of the market, subsequently creating knowledge in pursuit of continuous capital accumulation. Production of knowledge, therefore, becomes a mechanism to maintain the hegemony of the neoliberal-state and market, while establishing authority of capital on ontological position of man and society. In this context any intervention in the process of IoK under religious obligation is not just an epistemological, rather a moral impossibility within capitalist discourse. The relationship between the neoliberal-state, market and production of knowledge will enable the scholars of Islamic economics and finance to reassess their strategies pertaining to IoK.
\end{abstract}

KAUJIE Classification: J3, F1, F22

JEL Classification: P10, P16, P51, Z12

(C) 2020 JIBM. All rights reserved.

\footnotetext{
*Corresponding author: Omar Javaid

${ }^{\dagger}$ Email: omar.javaid@iobm.edu.pk
} 


\section{INTRODUCTION}

The project of the Islamization of knowledge and its corresponding institutions is underway for last sixty years or so. The urge of the resurgence of Islam has been manifested in two different dimensions, political (Ayubi, 1980) and epistemological (Siddiqi, 2011). Both processes have common agenda, that is, the revival of Islam in the determination of legitimate public order, but presume different causality to explicate the decline of the Islamic order in global historical context. The political resurgence movement considers the cause of the decline to be the fall of political order and epistemological backwardness is just one of the effects of the disintegration of Islamic statecraft. Therefore, it is claimed that the revival of Islamic epistemological tradition is not possible in absentia of Islamic state order. The epistemological movement on the other hand considers the disintegration of Islamic public order as the effect and the real cause of the fall in their epistemological backwardness. Hence, it is claimed that the revival of Islamic order is not possible without the revivification of Islamic epistemological discourse (Mawdudi, 1981).

The project of the Islamization of knowledge falls under the category of the epistemological dimension of contemporary movement of Islamic resurgence. Unlike the traditional puritanical notion of religious knowledge, the expounders of Islamization of knowledge have made serious attempts to diffuse the paradoxical duality of sacred and secular which persist in contemporary epistemological discourse (that is due to the domination of modern epistemological discourse). The malaise of Muslim community has been to discover the possibility of reconciling the religious epistemological tradition with modern secular sciences. The core project of the Islamization of knowledge is the systematic and comprehensive reconciliation of classical Islamic and secular scientific knowledge in an integrated whole to abolish the conventional bifurcation of sacred and secular knowledge as found in Christian ecclesiastical discourse (Metzger, 2003).

This reconciliation, however, ignores the ontological and epistemological contexts of the modern market system within which the structure of secular scientific knowledge is shaped along with the power-discourse relation which drives its direction. The Islamization of knowledge, without much influencing the hegemony of the said structure, attempts for its Shariah compliance, which involves removing haram elements from the structure. Much of this work has been done in an attempt to Islamize economics, which rather has taken the direction of Islamizing the modern financial institution. Zaman (2016) succinctly argues that modern Islamic economics has turned out to be 'Capitalism-interest-gambling $+z a k \bar{a} h$ '. Such an approach has allowed the ideological influence of the capitalist discourse (neoliberal to be specific) to determine the meaning, purpose and direction of evolution of Islamic prescriptions inserted into the western economics discourse (Javaid, Mahmood, \& Shamsi, 2018). The result is production of a body of knowledge which is labeled as Islamic, but is not Islamic in its essence particularly because of its failure to produce results any different from its western counterpart (Rethel, 2011).

Perhaps one of the key reasons for this failure is the ignorance of the metaphysical ideas which establishes the legitimacy of the modern free market (established by neoliberal ideology) along with its power system which drives direction of any transformational attempt. 
Therefore, while Islamizing knowledge pertaining to economics and finance (or any other related domain of knowledge), it is important to look at the possibility of Islamizing the philosophical foundation of the modern free market. In this context the paper introduces Hayek's philosophical defense of the free market system and Foucault's thesis of powerdiscourse relation, to explain the nature of philosophical grounds upon which modern knowledge of economics and finance is standing. This would allow scholars in Islamic finance and economics to rethink the contemporary depth, scope and strategy to develop Islamic economics and finance in contrast to its western counterpart.

The paper will first explain the significance of understanding the structure of knowledge prevalent within a civilization grounded in its worldview and philosophical paradigms. This will be followed by two sections. The first one will explain the philosophy of mind developed by Hayek and his compatriots who articulated a justification for the existence of the free market system as naturally organized around the original functioning of a human mind. The next section will discuss how Foucault explained the relationship between power and the dominant discourse prevalent in a society. Then we will compare the philosophical position of modern knowledge structure with that of Islam's to identify any possibility of reconciliation of the two. This will be followed by the implications of the discussion on the future direction of Islamization of knowledge in general and Islamization of economics in particular. The last section will conclude.

\section{The Structure of Knowledge}

In view of Schumacher (1973), modern knowledge is grounded in certain metaphysical assumptions or axioms. These axioms attempt to answer the perennial questions like: What is life? What is reality? Who are we? What is our purpose in this life? How to differentiate truth, right and good from falsehood, wrong and bad? How do we know the answer to these questions? Etc. The supposition about the nature of things (mankind, natural resources etc.) are generally referred as ontological axioms, suppositions about the purpose of things are referred as teleological axioms, while suppositions about the best ways to finds the answer to the perennial questions are referred as epistemological axioms. In view of Asutay (2007), "foundational axioms, values system and ontological and epistemological sources" create the foundation to determine the "operational principles/mechanisms", which in turn set up ground to establish the "functional institutions" and "specific methodology (or technique)" (pp. 2-3). Others also who have attempted to explain the connection between the metaphysical axioms and applied knowledge developed in a certain society Carl Menger (cited in de Soto, 2009; Greif, 1994; Mokyr, 2010).

The cited authors have also argued that every society standing on a unique set of metaphysical axioms would create its own set of socioeconomic and political institutions. Therefore, knowledge pertaining to the establishment and operational management of these institutions would eventually be grounded in the metaphysical axioms upheld by a society. More specifically, the knowledge pertaining to the design of market, state and social institutions and their interrelation will be driven by the presumed nature and purpose of man (or woman), the nature of life and death, the relationship of man with the world around him and the assumed 
methodology to acquire the necessary knowledge which answers the respective perennial questions. Figure 1 shows the emergence of structure of knowledge from the metaphysical axioms or foundation of a particular society.

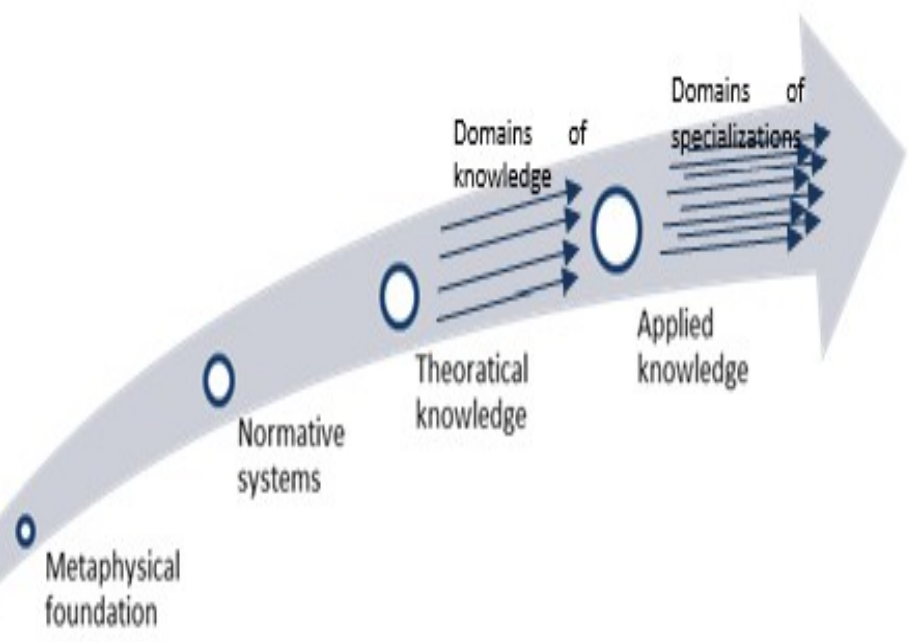

FIGURE 1. Structure of knowledge

For example, if the purpose of man is to maximize his potential through maximization of his freedom (function of the capital he owns), then perhaps he could do so better in a modern free market (Reisman, 1998). In such a society, education system, social and political order, would be instrumentalized to facilitate the free market system to enable every subject to maximize his freedom through maximization of return on capital. Such a society has been referred as a market society in relevant literature (Polanyi, 1944). The modern enlightened man in a market society is expected to use his observational (empirical) and intellectual (rational) capacities to find the optimum way toward the accomplishment of his purpose and find efficient ways to exploit any natural resource available at his disposal. In other words modern man (or woman) is a self-determined, autonomous and rational being committed to maximization of his potential through maximization of freedom which is otherwise obstructed with any pre-modern sources of knowledge such as culture, religion or intuition (Javaid \& Hassan, 2013; Reisman, 1998).

However, any corpus of knowledge emerging from pre-modern sources is accepted when empirical evidence confirms its ability to facilitate the purpose of modern man and society. Case in point is popularity of contemporary Islamic finance discourse within modern free market system. Acquisition of knowledge by the modern self-determined man, to advance toward his ultimate purpose of existence, is a peculiar phenomenon from the point of view of modern epistemological paradigm, which assumes mind of a man (or woman) to be a product of phenomenon of evolution.

The perspective on how a modern man acquires, interprets and implements knowledge has profound implication on his economic behavior in the market and on the kind of market order where the respective behavior can be exercised (more on this in the next section). The 
Questions about how a modern man would optimally acquire and process knowledge to fulfill his purpose of existence in a market society have been answered by Hayek which will be discussed in the next section.

\section{Hayek's Philosophy of Mind}

Hayek (1952)'s defense of the free market system is grounded in his philosophy of mind. Hayek (1952) believed that our mind organizes any new piece of information we acquire through our five senses in the context of what we already know. Our prior knowledge, experience, beliefs, values, world view, and hard-wired-natural-instincts influence how new sensory information is understood, appreciated or even dismissed. Hayek refers the collection of knowledge stored in a brain as 'Sensory Order' which is defined as a neural network which stores our sensory experiences. This implies that the meaning associated with each new experience is not embedded in the experience, it is rather constructed inside a human mind. Sense is made of new sensory information only if the mind is able to connect it with the previous stored information; if not then difficulty is experienced in making sense of a novel piece of information. Before Hayek, Adam Smith, explained the dynamics of sense making phenomenon inside human brain. Loasby (2004) explains in this regard:

"Smith argued that it is characteristic of human nature to be uncomfortable when unable to make sense of some phenomenon, especially when that phenomenon is repeatedly encountered, and that people therefore attempt to achieve comfort by the invention of "connecting principles". The discomfort occasioned by a subsequent failure to accommodate some new phenomenon within an established pattern then provides the stimulus to create a new interpretative system by a rearrangement of connections" ( $p$. 107).

We comprehend new information once it makes sense to us. Sense making, therefore, precedes comprehension of new sensory information. Comprehension is a result of 'linking activity', that is, new sensory experience making connections with previously stored sensory information in side our brain rather than a true representation of the objective reality. It is entirely possible that two individuals having a different set of background may interpret the same experience in a unique way or two different experiences in the same way. Information received is filtered implying that some attributes of the sensory experience may be involuntarily filtered out based on its irrelevance to the sensory order. As otherwise "there would be no hesitation regarding meaning; the order of our ideas would simply conform to the order of the world, doubt would be eliminated" (Dempsey, 1996). The "domestication of our sensory experience" (Dempsey, 1996) effortlessly and almost instantly inside our minds, therefore, allow us to ascribe meaning to information which may facilitate us in our endeavors only. As otherwise, we will become overwhelmed and perhaps paralyzed by the sea of sensory information arriving continuously through our senses.

In Dempsey's (1996) view, Hayek's theory of mind leads to following four conclusions which are (a) "that the mind is self-referential" ( $p .16)$, (b) "mperfection is a condition of the mind", (c) that the mind evolutionary is perpetually evolving, and (d) that a layer of the mind is unknowable to the conscious self (ibid).

(a) 'The mind is self-referential': This implies that each individual's mind will have its own 
unique set of sensory order built exclusively through the observations and experiences. Even if a group of individuals share a certain language, culture, background, and belief system, still the possibility of each individual interpreting the same sensory experience in a dissimilar way cannot be ruled out. So in view of Hayek (1952), "much that we believe to know about the external world is, in fact, knowledge about ourselves; it is a disclosure of who one is historically" (p. 6-7).

(b) 'Imperfection is a condition of the mind': We filter out information which is irrelevant to us, while only linking information which connects or make sense in context of our preexisting 'sensory order'. This implies that we never grasp a complete picture of reality, but the one which makes sense in context of our sensory order. Loasby (2004) while referring to Adam Smith also suggested that "the desire for theoretical comfort might induce people to reject part of their sensory order... 'to preserve the coherence of the ideas of their imagination." (p. 107-108). Hayek, therefore, argued that we need to rethink our assumption about the truthfulness of our awareness about experiences which may be entirely inaccurate including his own understanding of neuropsychology. Our own understanding of the world, therefore, must never be dogmatized, in Hayek's view, and always be open to criticism (Loasby, 2004). (c) "The Evolutionary Mind": The mind is designed to constantly update its sensory order which is essential to human survival in an ever changing world; therefore, any resistance to change our preconceived understanding of things can be a threat to our survival of species. Our mind is designed to adapt and upgrade its sensory order, therefore, should allow changes as and when new information arises about our surroundings. This shall continue indefinitely so that we may dwell in the vastness of infinitely expansive reality. Any assumption about the completeness of understanding about the world is a fatal mistake. Therefore, when we encounter a novel experience for the first time, we may allow our sensory order to naturally reorganize for the sake of its assimilation. The successful adaptation of the sensory order to the new sensory information leads to the biological evolution of human mind. (Dempsey, 1996).

(d) "The Unknowable Mind": The mind in Hayek's view performs this linking process of new and stored sensory order in ways unknowable to our conscious mind. The process is so complex that perhaps our conscious mind cannot perceive it. We can access our sensory order which contains all sensory experience; however the background process is not visible to us. It is like looking at some information on a computer screen, but not knowing how it has been processed inside the computer (Dempsey, 1996).

Due to the aforementioned properties of our sensor order, the prediction of any human behavior in any circumstances will remain probabilistic irrespective of the richness of relevant past data available to us. If the mind of a single individual is unpredictable, and his responses are based on subjective evaluation of his stimuli, then how come it can ever be possible to predict the behavior of an economy based on the cumulative motivation of countless actors? Therefore, it is inferred that the order in the market is a result of "an arrangement that evolves in a gradual and decentralized way and that constitutes an unintended result of the motivations and actions of many interacting individuals-not human design" (Dempsey, 1996, p. 34). It is not possible to grasp what happens inside the sensory order of millions 
of minds, let alone one, interacting with each other, therefore, any attempts to control the demand or supply of any product or service, or their prices, in a predictable way is a fallacy. According to Hayek (1989):

"It is indeed the source of the superiority of the market order, and the reason why, when it is not suppressed by the powers of government, it regularly displaces other types of order, that in the resulting allocation of resources more of the knowledge of particular facts will be utilized which exists only dispersed among uncounted persons." (p. 4).

\section{Theory of Evolution, Human Mind and Division of Labor}

The production of knowledge in the free market system carries an incentive proportional to the value of knowledge created unlike in the planned economies where rewards are not tied to the level of one's contribution to economic growth (Ericson, 1991). This goes against the basic functionality of human mind, where imagination leads to action with an expectation of a reward which if provided, reinforces the action within the human brain. In a free market system, a human brain can imagine to expect a reward in proportion to the value of its imagined initiative. This is unexpected in a planned economy. Loasby (2004) explains that this reward system is compatible with the functioning of a human brain:

[human] [brain] works by linking the idea of an initial sensation received by the body with the idea of an action which the body performs in response, and then linking the latter with the idea of an sensation that is interpreted as a consequence of that action. If the latter linkage produces a pleasurable sensation, then the linkage from initial sensation to action is strengthened, and if the sensation is unpleasant it is weakened ( $p .109)$.

Alfred Marshall believed that human mind works on two different levels, a higher and a lower one. At a higher level imagination and ideas emerge, while the lower level manages the routines activities. The imagination often encourages novel action with an expectation of a reward, which if received after performing an action, a new routine is developed at the lower level of our mind. The mechanism leads to trial and error in free market system leading to new innovations. This opens the path of market driven research and development improving the chances of economic growth in comparison to the planned economy where the chances of receiving an expected reward is obscure (Raffaelli, 2003). Planned economies, therefore suppress the growth of the potential of human mind and knowledge., In view of Loasby (2004), this idea also conforms to Darwinian concept of selective breading; he states:

"[The approach taken is now] oriented to problems, the course of development is now influenced by purposive behavior. This does not conform to modern neo-Darwinian principles of variety generation; but it does not conflict with the broader Darwinian principle of selection at the practical level, as in Darwin's own example of selective breeding" ( $p$. 110).

The two levels, distributing the task of imagination, and routine management, is an example of division of labor occurring naturally inside a human brain for the sake of operational efficiency. Loabsy (2004) assimilates Marshall's view of brain with Darwinian perspective on evolution. He argues that a human brain has evolved to optimize energy consumption by dividing its process into two levels. The routine level inside human brain performs the usual day to day activities, which does not involves much creative thinking-consuming lesser 
brain energy-unless a situation arises which cannot be addressed through what is already known, and require some creative imagination, requiring higher amount of energy. Once the need arises, the problem is forwarded to a higher level inside human brain to imagine possible solutions which are tested through trial and error to identify an optimum solution. The solution which works, becomes part of the routine level thinking. The process requiring creative problem solving only activates once the need arise, not on every instance of executing a routine. This is an energy economizing activity naturally performed by brain through division of tasks. Such an understanding of a human brain creates a biological justification of division of labor outside a human body as well. It has been argued that imagination of a human mind is an instrument to transcend the limits of our "genetic evolution" (Loasby, 2004, p. 125). Motivation to achieve more drives imagination which allows human beings to go past their routines, experiment and learn new things, subsequently expanding both in their knowledge and potential, which is believed to be a precursor to the genetic evolution of our species. Loasby (2004) notes:

"Economic growth and the growth of knowledge both entail the division of labor in order to achieve an effective allocation of resources to the development of domain-specific cognitive modules within the economy and within society" (p. 124).

Even Adam Smith extended his "evolutionary theory of cognition" (Loasby, 2004, p. 108) to explain the phenomenon of division of labor as a profound mechanism for the growth of knowledge and economy, which was adopted by Charles Darwin to develop his theory of evolution to explain variety among species. Darwin concurred that division of labor has furthered "biological evolution towards the variety of species; and they have led human societies towards the variety of knowledge" (Loasby, 2004, p.124).

Once a domain of knowledge is formed, actors in each domain increasingly focus on the micro details of their specialization, perpetually increasing the depth of knowledge in their respective domain. From Hayekian perspective, the differences in the real world and the sensory order accumulated in each individual mind, open the possibility of exploration; hence the need of scientific analysis to discover what is real (Hayek, 1952). In an economy, different groups of individuals have different sensory experiences, offering a variety of venues to fill the gap between what is real and perceived, leading to "multifarious forms of division of labor" (Loasby, 2004, p. 123) consequently expanding human knowledge in a free market context. Loasby (2004) explains: "Hayek's account of the functioning of the human brain and neurocognitive theory both lead to the conclusion that human knowledge is dispersed and incomplete; furthermore, the combination of the wide-ranging potential of the human brain and the limited capacity of each particular brain to realize that potential implies that knowledge can become less incomplete only if it becomes more dispersed" ( $p$. 123).

The development of multifarious domains of knowledge-through the process of division of labour-facilitates better in the process of capital accumulation (Hayek, 1945), which may be difficult with blurred boundaries between domains. The unparallel growth of knowledge in variety of directions cannot be expected in a centrally planned economy. Any political body intervening in the process of free organization and evolution of knowledge within the economy will be an obstruction. A direction of growth of knowledge cannot be decided a-priori, 
or by any higher body, as it will only hinder in the expansion of "human consciousness and human purpose organized in a variety of cognitive patterns which suggest a variety of profit opportunities" (Loasby, 2004). The freedom to experiment and test the ideas emerging from the human imagination within each domain of specialization without restriction leads to the expansion of human knowledge. Any restriction posed by culture, religion, tradition or any political ideology in the process of expansion of human knowledge, therefore, needs to be avoided $^{1}$.

The process of trial and error for that matter produces waste, which has a cost; therefore, any mechanism which does not compensate for the cost incurred in the development of new knowledge would lag behind. Therefore, free market facilitates the growth of knowledge by commercializing it, analogously allowing the creation of only commercialize-able knowledge $^{2}$. It is therefore, not the accumulation of knowledge which leads to the accumulation of capital, rather the influence of the capital flows which allows the creation of knowledge to facilitate its growth and power.

\section{Foucault's Power-Discourse Thesis}

In Foucault's (1980) view, power in a society is exercised through a dominant discourse which legitimizes the political authority's control over its subjects. Without "production, accumulation, circulation and functioning of a discourse" the "social body" cannot be "permeated, characterized and constituted' suggests Foucault (1980, p. 93). The dominant discourse "produces and transmits" the truth, which subsequently "reproduce this power" (Foucault, 1980, p. 93). Foucault explains:

"We are subjected to the production of truth through power and we cannot exercise power except through the production of truth...we are constrained or condemned to confess or to discover the truth. Power never ceases its interrogation, its inquisition, its registration of truth: it institutionalizes, professionalizes and rewards its pursuit. In the end, we are judged, condemned, classified, determined in our undertakings, destined to a certain mode of living or dying, as a function of the true discourses which are the bearers of the specific effects of power" (Foucault, 1980, p. 93-94).

Within a free market system, the dominant discourse becomes a medium to define other discourses within multifarious domains of knowledge emerging in perpetuity. As discussed above a free market economy harbors countless domains of knowledge whose number keeps increasing with time. Experts in each domain attempt commercialization to compete with other domains, while some domains that become politically relevant, play a domineering

\footnotetext{
${ }^{1}$ For example, would it make sense in a religious society to find out ways to make death obsolete, or find out how life has been created accidently and evolved through billions of years, or how to conquer the process of genetic mutation to create life from inert substances, or how to build weapons of mass destruction which could kill women, children, elderly, planets, livestock or anything within the blast radius? If the answer is not in affirmation, then a non-religious-amoral society would perhaps want more questions to be answered than a religious one, subsequently raising question about the comparative capacity of a religious society to contribute in the overall sphere of knowledge (Huff, 1996)

${ }^{2}$ Discourse is a linguistic context, system of meaning, through which meaning of any communication within a domain of knowledge is determined. It is a common observation that similar terms are used in different domains may mean different things (for details see Javaid et al., 2018)
} 
role in shaping other domains in Foucauldian perspective. The dominant discourse prevalent within the politically significant domain(s) of knowledge instrumentalize(s) other domains of knowledge; it therefore, provides rules of interpretation for other discourses. In other words, the knowledge within a domain gets meaning from the context set by the dominant discourse in a society. If the discourse within the domain of knowledge comes in conflict with the dominant discourse, it is either subjected to reinterpretation or is rendered obsolete.

Each domain also posses its own rules of interpretation, forming a complex system where discourses remain apart, yet influence each other in a complex web of intrinsic and extrinsic linkages. The adjustment, "mutual stimulation" (Seidl, 2007, p. 209) and 'parallelization' of autonomous domains under the influence of a dominant domain's language has been described as 'structural coupling'. The key influencer in this interplay, adjustment, mutual stimulation and parallelization between domains of knowledge is the institution of power and authority. Foucault (1980) explains:

"Power must be analyzed as something which circulates, or rather as something which only functions in the form of a chain. It is never localized here or there, never in anybody's hands, never appropriated as a commodity or piece of wealth. Power is employed and exercised through a net-like organization. And, not only do individuals circulate between its threads; they are always in the position of simultaneously undergoing and exercising power. They are not only its inert or consenting target; they are always also the elements of its articulation. In other words, individuals are the vehicles of power, not its points of application" (p. 98).

In a free market system, individuals (mentioned in the quote above) can be capitalists, or mangers, or anyone committed to the process of accumulation of capital. The owners and employees of corporations, banks and other financial institutions in a free market are a fitting example. Each one of them, specializes in a certain domain of knowledge (shaped under the influence of the dominant discourse), and is connected to many other individuals within and outside his parent organization and work synchronously with other specialists. Each agent of the capital exercises his domain of knowledge in coordination with specialists of other domains, mutually establishing the legitimacy of the power of capital over the society. Power within a capitalist-free market-system is, therefore, also exercised through the interplay of knowledge experts, thought leaders and formal authorities shaping the meaning within their domains under the influence of dominant discourse. Wittgenstein's perspective of family resemblance also offers an analogy to understand the relationship between power discourse and interdependent domains of knowledge. The senior members of a family hold authority over junior members who influence the meaning formation for each junior family member particularly if the seniors also possess moral authority over juniors. Each junior member may have their own way of ascribing meaning to their experiences, while they also become influenced by senior members of the family. Peer influence peers, who are cumulatively influenced by the seniors in the family (Wittgenstein, 1985). In words of Foucault (1979): "[Power] produces reality; it produces domains of objects and rituals of truth. The individual and the knowledge that may be gained of him belong to this production" ( $p .194)$.

Looking more holistically to identify the origin of power in a free market society many (Keat, 1997; Polanyi, 1944; Toffler, 1980; Walzer, 1983) have argued that it is the market 
system which dominates and dictates the non-market institutions from politics to family. The surviving ability of a discourse within a domain of knowledge is dependent on its commercialization potential in a free market society. A mother's knowledge about how to up-bring the children comes in competition with the knowledge to manipulate children through mass marketing strategies, or religious knowledge to achieve salvation on the Day of judgement comes in competition with the knowledge which specializes in economic success in the market. The extra-market discourses, therefore, either have to prove their transferability (in context of their meaning) to participate in the accumulation of capital with competing discourses, or face extinction.
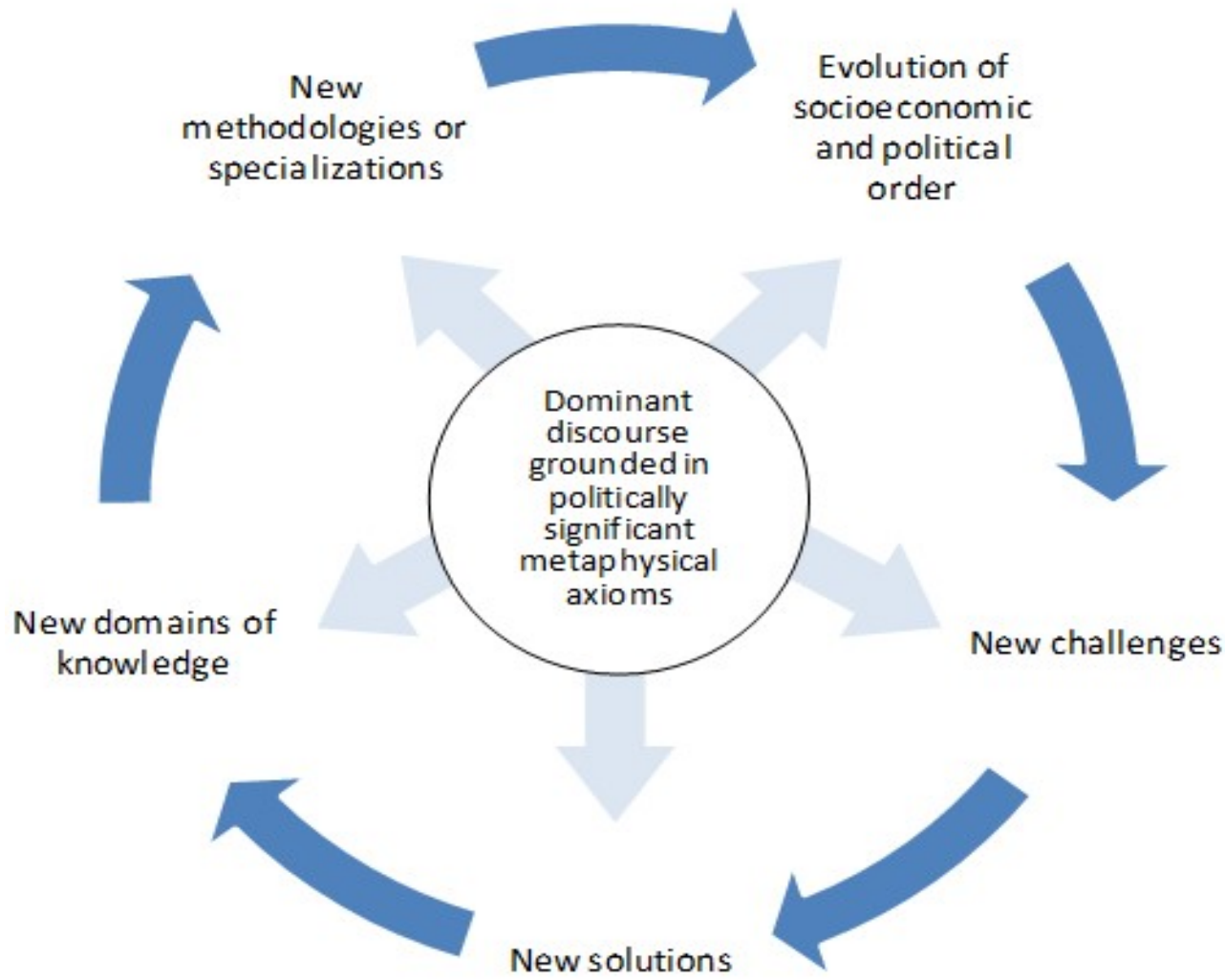

FIGURE 2. Evolution of knowledge in a modern society

Flow of power, therefore, is from the market to other institutions; subsequently the commercialize-able domains of knowledge dominate non-commercialize-able domains in a market society. On an organizational level also, it is not the professional, academic or religious orientation of employees and experts, rather than the market discourse which rationalize the tactical and strategic orientation of the firm (Hardy \& Thomas, 2014).

It is important to note that this interplay between domains of knowledge and instrumentalization of their respective discourse by the dominant one is happening under certain set of metaphysical assumptions embedded in the dominant discourse. In the market society, these assumptions are the very ontological, epistemological, cosmological and teleological axioms which emerged as a product of enlightenment thought (secular, modernist, capitalist and materialist) movement in Europe (Polanyi, 1944; Schumacher, 1973) and provide a criterion for any pre-modern discourse to exist within its dominion. 


\section{Possibility or Impossibility of Reconciliation of Islamic and Modern Spheres of Knowl- edge}

The preceding discussion on Hayek's theory of mind and Foucault's power-discourse thesis implies that the knowledge in a western free market system evolves to fulfill the requirement of growth of the modern-self-determined man and the modern economy. The objective of knowledge accumulation is exclusively to accumulate more capital or the growth of economy per se. The perpetual growth of sphere of knowledge to grow human potential is justified within the evolutionary pretext, which sees every life form as continuously evolving. The phenomenon of evolution allows creation of multifarious domains of knowledge ${ }^{3}$ through division of labor in a free market system. With perpetual evolution of knowledge the society evolves as a whole. Every solution to a problem leads to new challenges, therefore, opens new possibilities of research and development furthering the evolution of knowledge either through development of new domains or enrichment of existing ones (see Figure 2). Each new domain then competes with older ones in a free market, in the context of commercializing potential.

Those domains which lag behind in adaptation (with the changing market requirements) and commercialization go extinct. It is argued that this happens best when production of knowledge is widely dispersed and decentralized activity, while any form of control from above to regulate, restrict, subdue or direct this production can only hamper the process. The domain competes with each other in context with their ability of capital accumulation, implying the hegemony of capital over the development, adaptation and evolution of knowledge. The capitalist discourse, therefore, sets the rules in Foucauldian perspective, which become embedded into every domain of knowledge, subsequently establishes the authority of capital on the entire process. The dominant discourse also provides a means to interlink knowledge emerging within distinct domains. The following characteristics of knowledge can be established from the above discussion:

1. Knowledge is deemed fit if it can facilitate the modern man in growing his potential by maximizing freedom through capital accumulation which happens in a free market society through commercialization of latest research and development;

a. The purpose of knowledge is, therefore, to facilitate the evolution of modern man, a self-determined autonomous human (Javaid \& Hassan, 2013);

b. Every domain of knowledge is incomplete at any state, therefore, should accept to perpetually evolve; no body of knowledge can claim to be absolute and free from error;

c. The most adaptable and fittest (commercializable) domain is expected to survive and excel in a free market;

d. Scientific knowledge, therefore, is better than every other forms of knowledge as it never claims to be absolute and continues to evolve while correcting its past mistakes;

2. The modern free market system is the best place for unprecedented growth of knowledge, human potential and economy (Javaid \& Suri, 2015);

3. No political authority should direct or contain the growth of knowledge in any direction;

${ }^{3}{\overline{\text { Sphere of knowledge }}=\text { Domain }_{1}+\text { Domain }_{2}}+$ Domains $_{3} \ldots . .$. Domain $_{n}$ 
4. The dominant discourse, like capitalist discourse in free market society, will set the rules of interpretation of any domain or body of knowledge in context of the dominant metaphysical axioms (Javaid et al., 2018);

5. Every domain of knowledge within a society (like capitalist) will incorporate the language of power to reinforce the prevalent concept of power (sovereignty of capital) or otherwise expect confrontation from the dominant discourse (Lalonde, 1993).

The ontological, epistemological and teleological assumptions in Islamic world view stand in contrast with the one stated above. For example, the ultimate purpose of believing man or women in Islam is to seek salvation on the Day of Judgment by living a life in accordance with the teachings of Prophet (PBUH) and the holy book Qur'ān (Nadvi, 2005). Islam not just lists the prohibitions, but also vividly explains the ideal form of life one should live to achieve the highest reward on the Day of Judgment. All the knowledge pertaining to achieve this goal has been already been made available by the last Prophet (PBUH) and in the holy Qur'ān, which is believed to be the highest form of knowledge (uloom) in contrast to any other forms available to main kind. A person, who knows nothing but what has been taught by the Prophet (PBUH) and the holy book, can still fulfill his (or her) ultimate purpose, unlike the modern man who has much to discover. The teachings of Islam not just cover the details pertaining to ritual worships but also provide the best practices for unifying organization of the social, economic and political life in a way that it allows every Muslim in a society to fulfill his or her ultimate purpose. In this context, no aspect of one's existence has been left uncovered in the knowledge presented by Qur'ān and Sunnah, making it a complete code of life ${ }^{4}$. The fundamental teachings of Islam are immutable and will remain so till eternity. Consequently, the top scholarship within an Islamic society is the one who does not create rather preserves and transmits the teachings of Islam in general; they may also do ijtihad to determine the legitimacy in context of novel circumstances as and when required.

Existence and development of worldly domains of knowledge, which may be referred as technical knowledge or funoon (in contrast to uloom $^{5}$ ), is sanctioned and directed by the top scholarship in compliance with the metaphysical axioms about the life and world advocated by the teachings of Islam. In this context, technical knowledge pertaining to agriculture, textile, construction, transportation, weaponry, metal and wood works, health care or any domain which may facilitate the life in an Islamic society would be encouraged. For example, finding ways to manufacture items of need with the least amount of resources, wastage and pollution will be valued in an Islamic society. Political authority of an Islamic society would encourage or discourage the development of any domain of technical knowledge as directed by the top Islamic scholarship. Any domain of knowledge questions the sovereignty of the almighty and goes against the normative premise of Islamic uloom. It may also be deemed off limits by the top Islamic scholarship (Huff, 1996) who may even authorize the use of force by the political authority to contain it. Table 1 compares the characteristics of modern Islamic spheres of knowledge.

\footnotetext{
${ }^{4}$ See the holy Qur'ān, surah al-Ma'idah, verse 3

${ }^{5}$ The terms uloom and funoon has been used in the same meaning in traditional literature of the sub-continent region (see Abdul-Hae, 1970)
} 
TABLE 1

Comparison Between Characteristics of Modern and Islamic Spheres of Knowledge

\begin{tabular}{|c|c|c|c|}
\hline Sr. No & Characteristics & Modern & Islamic \\
\hline 1 & $\begin{array}{l}\text { Ultimate objec- } \\
\text { tives }\end{array}$ & $\begin{array}{l}\text { Enable the evolution of } \\
\text { modern man, to make } \\
\text { him god-like, by enhanc- } \\
\text { ing the possibilities of his } \\
\text { freedom and progress }\end{array}$ & $\begin{array}{l}\text { Facilitate a believing } \\
\text { Muslim in achieving } \\
\text { salvation on the Day of } \\
\text { Judgment }\end{array}$ \\
\hline 2 & $\begin{array}{l}\text { Tactical objec- } \\
\text { tive }\end{array}$ & $\begin{array}{l}\text { Conquering natural world } \\
\text { to achieve the ultimate ob- } \\
\text { jective of modern man }\end{array}$ & $\begin{array}{l}\text { Create a society facilita- } \\
\text { tive toward the ultimate } \\
\text { objective of a Muslim }\end{array}$ \\
\hline 3 & Source & Human mind & Uloom: Revelation \\
\hline & & & $\begin{array}{ll}\text { Funoon: } & \text { Wisdom and } \\
\text { intellect } & \text { ordained to } \\
\text { mankind } & \end{array}$ \\
\hline 4 & Nature & $\begin{array}{l}\text { Always incomplete and } \\
\text { relative; continuously } \\
\text { evolving and adapting }\end{array}$ & $\begin{array}{l}\text { Uloom: Immutable, com- } \\
\text { plete and absolute }\end{array}$ \\
\hline & & & $\begin{array}{l}\text { Funoon: Need driven de- } \\
\text { velopment }\end{array}$ \\
\hline 5 & Fitness criteria & $\begin{array}{l}\text { Continuously evolving } \\
\text { with increasing com- } \\
\text { mercializablility in free } \\
\text { market }\end{array}$ & $\begin{array}{l}\text { Conformance to Qur'ān } \\
\text { and Sunnah }\end{array}$ \\
\hline 6 & Best form & $\begin{array}{l}\text { Scientific knowledge pro- } \\
\text { duced in a free market }\end{array}$ & Qur'ān and Sunnah \\
\hline 7 & $\begin{array}{l}\text { Medium of de- } \\
\text { velopment }\end{array}$ & Modern free market & $\begin{array}{l}\text { Uloom: No development } \\
\text { required in general, reli- } \\
\text { gious scholarship may do } \\
\text { ijtihad to develop rulings } \\
\text { pertaining to novel cir- } \\
\text { cumstances when needed } \\
\text { Funoon: Any segment } \\
\text { of Muslim society, gen- } \\
\text { erally excluding top reli- } \\
\text { gious scholarship }\end{array}$ \\
\hline
\end{tabular}


TABLE 1 continue

\begin{tabular}{|c|c|c|c|}
\hline Sr. No & Characteristics & Modern & Islamic \\
\hline \multirow[t]{2}{*}{8} & $\begin{array}{l}\text { Motivation for } \\
\text { Production }\end{array}$ & $\begin{array}{l}\text { Maximization of freedom } \\
\text { through capital accumulation; } \\
\text { overcoming the barriers to } \\
\text { freedom, equality and progress } \\
\text { being faced in the evolution } \\
\text { and restructuring of modern } \\
\text { society }\end{array}$ & $\begin{array}{l}\text { Uloom: Not produced, rather } \\
\text { preserved and learnt to seek sal- } \\
\text { vation in hereafter }\end{array}$ \\
\hline & & & $\begin{array}{l}\text { Funoon: Facilitation of the } \\
\text { wellbeing of public in general } \\
\text { in a Muslim society }\end{array}$ \\
\hline \multirow[t]{2}{*}{9} & $\begin{array}{l}\text { Role of politi- } \\
\text { cal authority in } \\
\text { production of } \\
\text { knowledge }\end{array}$ & Preferably needs to be avoided & $\begin{array}{l}\text { Uloom: None, though sup- } \\
\text { port the religious scholarship in } \\
\text { preservation and propagation } \\
\text { of Islamic knowledge }\end{array}$ \\
\hline & & & $\begin{array}{l}\text { Funoon: May facilitate re- } \\
\text { search and development of mil- } \\
\text { itary hardware, for example. }\end{array}$ \\
\hline 10 & $\begin{array}{l}\text { Dominant dis- } \\
\text { course }\end{array}$ & $\begin{array}{l}\text { Capitalist axioms and material- } \\
\text { ist worldview }\end{array}$ & $\begin{array}{l}\text { Islamic philosophy and world } \\
\text { view }\end{array}$ \\
\hline 11 & $\begin{array}{l}\text { Political objec- } \\
\text { tives }\end{array}$ & Sovereignty of capital & Sovereignty of almighty Allah \\
\hline
\end{tabular}

Looking at the difference between foundation and direction of the two spheres of knowledge explained above, the question of reconciliation between the two becomes more difficult to answer. Each of the two spheres creates opposing socioeconomic and political order (Gellner, 2000). Each order harbors a distinct set of challenges, whose solution can only be sought from the prevalent sphere of knowledge within the respective society. It would be unwise to assume that the solution to the challenges emerging within a free-market society in achieving its goals may necessarily be available in Islamic sphere of knowledge, and vice versa. Likewise, removing certain elements prohibited by Islam from a domain âĂŞ like the concept of interest and gambling from modern economics and finance âĂŞ without much affecting the larger structure of knowledge may not be termed as a revival of Islamic discourse. Rethel (2011) argues:

"The push of Islamic finance to achieve more credibility and 'sophistication' to become an investable alternative for the mainstream makes it awkwardly dependent on existing knowledge and power structures (ofconventionaleconomics\& finance)... Hence, the existing power and knowledge structures in global finance create an environment in which Islamic finance serves to reproduce (whatalreadyexists) ... It remains to be seen whether Islamic finance will be able to emancipate itself from existing knowledge and power structures or 
whether it will end up as the paradox of 'secularized Islamic finance', a reproduction of conventional finance with a few cosmetic changes, Islamic only in name" (p. 93).

It is argued here, that the root of the mistake lies not in the ill intentions of concerned scholars involved in the process of Islamization of knowledge, rather in ignorance about the nature and effects of the dominant capitalist discourse within which Islamization has been attempted. As a result the project of Islamization is perhaps turned into modernization of Islamic sphere of knowledge through reinterpretation of Islamic concepts (like the ones in Islamic finance) in context of the dominant capitalist discourse and their subsequent instrumentalization for the goals of a free market (Javaid et al., 2018).

\section{Implications for future work in Islamization of Economics}

Before working out a plan to Islamize any domain of knowledge, like economics, within the modern sphere of knowledge, one should ask: Why economics as a domain of knowledge was even created in the first place? The question is significant in the context of the process of knowledge creation in the modern society. Any domain of knowledge addresses the requirements of a society built on a certain metaphysical axioms. The significance of a domain, its evolution, or further division into more sub-domains is again subjected to the challenges emerging within a socioeconomic and political order where the domain has been developed. In this context, modern economics and its sub domains like finance and business management, and its higher level domains like evolutionary psychology and philosophy (Gray, 2007), are a product of a certain metaphysics which assumes that the behavior of the modern man is driven by his material self interest who indulges in the process of exchange for the sake of maximizing utility irrespective of any social ${ }^{6}$ or spiritual considerations. Modern economics is, therefore, a study of the economic behavior of modern man, a homo-economicus, a product of genetic evolution of billions of years. Like every other domain of knowledge, modern economics is also imperfect; therefore, require perpetual advancement-evolution-to perpetually facilitate evolving requirements of a modern man. Due to dominant capitalist discourse, modern economics is also considered relatively more important than other domains of knowledge (Javaid \& Suri, 2015).

Does a domain of knowledge would exist in a similar fashion within the Islamic sphere of knowledge? Is there a place of homo-economicus anywhere within an Islamic worldview? Is a Muslim expected to trade, while only focusing on his material self-interest, devoid of any social and spiritual considerations? Is economics a politically significant domain within Islamic worldview like it is in a capitalist society? If the answer to these questions is not in affirmation, then should Muslim scholars even consider economics, or any other similar domain, worthy of Islamization? ${ }^{7}$ Is it even possible to cleanse modern economics from the influence of the metaphysical ideas, like the ones emerging from evolutionary biology and psychology which perhaps assume homo-economicus as an evolved version of homo-sapiens, a product of genetic evolution of billions of years, who do not have any purpose other than

\footnotetext{
${ }^{6}$ Study of social capital (Portes, 1998; Woolcock, 1998) suggests otherwise, however, it is more of a domain of sociology then of economics

${ }^{7}$ Also see (Zaman, 2014)
} 
to serve his material needs, who aspire to be free from any religious restriction or political dogmatism? Metaphorically speaking, can we take a locomotive, remove its chassis and engine, and reassemble the leftover components to create a boat which we need to cross a river and that also with tools and equipments designed to assemble a locomotive? It would be better to create a functioning boat from scratch perhaps; irrespective of how crude it looks, because the ultimate objective is to cross the river. If we need a boat, why even think modifying a locomotive. In context of the metaphor, one may ask, do we even need a discipline called economics in the Islamic sphere of knowledge, let alone Islamize modern economics for that matter?

During the colonial period, foreign occupiers forcefully replaced traditional economic and political institutions with the ones designed for another civilization, subsequently bringing in challenges which could not be contextualized in the light of historical experience and knowledge Muslims already possessed. Many falsely associated the cause of this fall to inability of Muslims to excel in the domains of modern domains of knowledge and institutions despite historical analysis standing in disagreement ${ }^{8}$. Nevertheless, a significant majority of the scholarship, who concurred with the idea of bringing the change from within, is now perplexed by the futility of their original plan (Islahi, 2015). The difference between desired and actual results of Islamization of knowledge in general and Islamization of economics and finance in particular are the most popular examples.

Alternatively, the scholarship needs to first workout the root cause of the problems being faced by the Muslim world right now. Many of these problems can be caused by living in compliance to the modern ways of organizing individual and collective lives. Some of these problems can perhaps be solved by avoiding modern methods. There are many examples among the entrepreneurial communities in Pakistan (like Memon, Delhi saudagaran, Chinioti, \& Bohri). Entrepreneurs within these communities, for example, avoid banking system altogether yet claim to have more stable growth of their businesses. Some of them even claim that living a simple and modest lifestyle can improve stability and resilience within family and business, while pursuing modern living standards leads to the contrary (Javaid, Shamsi, \& Hyder, 2019). Muslim scholarship can, therefore, study such examples to determine if certain problems can be avoided among Muslim societies by simply shunning the modern systems and standards.

On a more academic level pertaining to so called Islamic economics, it needs to be noted that principles of trade in Islamic jurisprudence, are equally concerned about the social and spiritual aspects of a process of economic exchange. Speculative transactions are not allowed, for example, because they may end up creating a dispute between trading parties. rib $\bar{a}$ is defined as a war against Allah and Prophet Muhammad (PBUH) rather than source of economic inequality and injustice. A historical review of Muslim markets also suggests that behavior of traders was not mere determined by economic considerations, but also by social and religious considerations (Javaid, 2015). Therefore, study of a Muslim market, would not just be a

\footnotetext{
${ }^{8}$ Khaldun has explains this phenomenon in detail (see Mohammad, 1998). Case in point: Fall of Muslim civilization in 13th century CE against the Mongol invasion particularly when Muslims were excelling in the domain of scientific research. The fall of Muslim Spain in 12th century against the crusaders is another example. For a review on causes of collapse on previous civilizations see Tainter (1988)
} 
study of economic behaviors of traders, but also of the social and spiritual implications of the trade process. The study of Muslim markets would also be much concerned about the normative evaluation of behaviors as opposed to a positivist stance of modern economics (Zaman, 2014). Due to difference in context, scope and objective, a different term for the subject is, therefore, required.

On a discourse level, the argument for an alternative of modern economics and its all related subject, acknowledges the legitimacy of the division of knowledge as it has occurred in a capitalist order. The modern domains are a product of the ongoing experience of a modern man accumulated while addressing challenges faced in the process of accomplishing his objectives in a modern capitalist society. In this context perhaps, as Muslims we do not need an alternative in its literal sense. We need solutions to the socioeconomic and political problems faced by a significant number of populace in the Muslim world. The experience of the modern civilization is the last place we should look towards, for the reasons elucidated above.

As of now, a unique structure of knowledge grounded in the metaphysical axioms of Islam may be erected or identified from the existing corpus of knowledge available to Muslim civilization. For example, the structure of Qur'ān, or the way concepts are organized within Qur'ān, implies that the knowledge can be organized in ways other than employed within modern sphere of knowledge. Once the structure is re-enacted, then modern knowledge can be studied along with its metaphysical foundation, to see what can be borrowed to fix any problem within Muslim world. It is like creating an artificial body part, like a kidney, which requires comprehensive knowledge of not just human body, but of electronics, electrical and mechanical engineering as well. This is opposed to the absurd strategy of cutting body part of a human being to be inserted in an artificially constructed humanoid for the sake of saving a human life.

The restoration of an Islamic structure of knowledge would perhaps also require analogues creation of an Islamic socioeconomic and political order ${ }^{9}$, as otherwise it would stand on theoretical and hypothetical grounds. Whatever the strategy maybe, the prerequisite is a united effort by the entire Muslim scholarship which unfortunately is divided in their approach toward Islamization, though united in their acceptance toward the modern spheres of knowledge and resulting institutional frameworks. Nevertheless, the very term 'Islamization' implies working with a corpus of knowledge which is not Islamic in its essence in the first place, which cannot be Islamized while ignoring the very essence which if removed will rather disintegrate the corpus upon which the Islamization has to be performed. The paper, therefore, argues against the legitimacy of such a strategy, and attempts to present an alternative, as discussed above.

\section{CONCLUSION}

Free market system, as desired by the neoliberal ideology, is expected to operate with minimum political intervention. Intervention-less operation of free market, it is believed, is

${ }_{9}^{9}$ On a much smaller scale perhaps, like in a village, as opposed to Islamizing an entire nation. Smaller examples can be scaled up and replicated once proven successful. 
the best mechanism to continuously create countless domains of knowledge through the phenomenon of division of labor, a necessary precondition for the perpetual evolution of homo-sapiens. Homo-sapiens are believed to be on the path of evolving into something better than any other species, equivalent to gods (Suri, 2007), through their pursuit to control nature including the fundamental constituents of life and death. This control is only possible through unprecedented growth in knowledge for which the best mechanism is believed to be free market system. How would such a system of knowledge would respond or affect any attempts on its Islamization?

The pursuit to Islamize the stream of knowledge emerging from the modern free market is typically done without taking into account the fundamental nature of the structure of knowledge being Islamized. The result is perhaps the modernization of Islamic discourse, instead of the contrary. The primary cause, in view of the authors, is the ignorance about metaphysical foundations upon which the modern structure of knowledge is standing. Understanding of these foundations shall be one of the primary goals of any scholar working in the domain of Islamization, as otherwise the results may be contrary to expectations. The picture of the metaphysical foundations of the modern structure of knowledge, sketched in the paper, only suggests that it is unwise to attempt Islamization within the modern structure. On the contrary, a structure of knowledge built on the metaphysical foundation of Islam is perhaps required before attempting Islamization of any piece of knowledge created within the modern structure of knowledge. To begin work on the development of such an independent structure âĂŞ free from the influence of modern structure of knowledge-should be the first and foremost priority of scholars working on the project of Islamization. In such a pursuit an in-depth understanding of structure of its western counterpart and the metaphysical foundation upon which it stands is also a precondition.

\section{REFERENCES}

Abdul-Hae, M. H. S. (1970). Islami uloom-o-funoon hindustan main. Uttar Pardesh, India: Darul-Musannafeen Azam-Gadha.

Asutay, M. (2007). A political economy approach to Islamic economics: Systematic understanding for an alternative economic system. Kyoto Bulletin of Islamic Area Studies, 1(2), 1-15.

Ayubi, N. N. M. (1980). The political revival of Islam: The case of Egypt. International Journal of Middle East Studies, 12(4), 481-499. doi: https://doi.org/10.1017/S0020743800031263

de Soto, J. H. (2009). Economic cycles.money, bank credit and economic cycles. Alabama, AL: Ludwig von Mises Institute.

Dempsey, G. T. (1996). Hayek's terra incognita of the mind. The Southern Journal of Philosophy, 34(1), 13-41. doi: https://doi.org/10.1111/j.2041-6962.1996.tb00774.x

Ericson, R. E. (1991). The classical soviet-type economy: Nature of the system and implications for reform. The Journal of Economic Perspectives, 5(4), 11-27. doi: https://doi.org/10.1257/jep.5.4.11 
Foucault, M. (1979). Discipline E punish: Birth of a prison. Harmondsworth, UK: Penguin Books.

Foucault, M. (1980). Power/knowledge: Selected interviews and other writings 1972-1977. New York, NY: Pantheon Books.

Gellner, E. (2000). Trust, cohesion, and the social order. In D. Gambetta (Ed.), Trust: Making and breaking cooperative relations (pp. 142-157). Oxford, UK: Basil Blackwell Publishing.

Gray, P. (2007). Psychology (5th ed.). New York, NY: Worth Publishers.

Greif, A. (1994). Cultural beliefs and the organization of society: A historical and theoretical reflection on collectivist and individualist societies. Journal of Political Economy, 102(5), 912-950. doi: https://doi.org/10.1086/261959

Hardy, C., \& Thomas, R. (2014). Strategy, discourse and practice: The intensification of power. Journal of Management Studies, 51(2), 320-348.

doi: https://doi.org/10.1111/joms.12005

Hayek, F. A. (1945). The use of knowledge in society. The American Economic Review, 35(4), 519-530.

Hayek, F. A. (1952). Sensory order: An inquiry into the foundations of theoratical psychology. Illinois, IL: University of Chicago Press.

Hayek, F. A. (1989). The pretence of knowledge: Nobel memorial lecture, December 11, 1974. American Economic Review, 79(6), 3-7.

Huff, T. E. (1996). Can scientific knowledge be Islamized? Social Epistemology, 10(3-4), 305-316. doi: https://doi.org/10.1080/02691729608578821

Islahi, A. A. (2015). First vs. second generation Islamic economists: Deviations and differences in thoughts. In H. A. El-Karanshawy, A. Omar, T. Khan, S. Syed Ali, H. Izhar, W. Tariq,.....B. Al Quradaqhi (Eds.), Developing inclusive and sustainable economic and financial systems-Islamic economics: Theory, policy and social justice (Vol. 2, pp. 11-22). Doha, Qatar: Blooms Bury Qatar Foundation Journals.

Javaid, O. (2015). The original socio-Cultural and economic context for practicing shirkatul-aqd. International Journal of Pluralism and Economics Education, 6(4), 371-385. doi: https://doi.org/10.1504/IJPEE.2015.075854

Javaid, O., \& Hassan, M. (2013). A comparison of Islamic and capitalist conception of economic justice. International Journal of Economics, Management and Accounting, 21(1), 1-31.

Javaid, O., Mahmood, N., \& Shamsi, A. (2018). The loss in meaning: influence of strategy language and modern financial discourse on the working concepts in islamic banking and finance. Pakistan Business Review, 20(2), 438-448..

Javaid, O., Shamsi, A., \& Hyder, I. (2019). How Memon, Delhi Saudagaran and Chinioti entrepreneurs create new ventures? Pakistan Business Review, 21(1), 63-73.

Javaid, O., \& Suri, A. W. (2015). Global financial capital vs . Islamic concept of wealth: The question of ideological dominance. Journal of Islamic Business and Management, 5(2), 117-134. doi: https://doi.org/10.12816/0026420 
Keat, R. (1997). Colonisation by the market: Walzer on recognition. Journal of Political Philosophy, 5(1), 93-107. doi: https://doi.org/10.1111/1467-9760.00025

Lalonde, M. P. (1993). Power/knowledge and liberation: Foucault as a parabolic thinker. Journal of the American Academy of Religion, 61(1), 81-100. doi: https://doi.org/10.1093/jaarel/LXI.1.81

Loasby, B. J. (2004). Hayek's theory of the mind. Evolutionary Psychology and Economic Theory Advances in Austrian Economics, 7(1), 101-134. doi: https://doi.org/10.1016/S1529-2134(04)07006-1

Mawdudi, S. A. A. (1981). A short history of the revivalist movement in Islam. Delhi, India: Markazi Maktaba Islami.

Metzger, P. L. (2003). The word of christ and the world of culture: Sacred and secular through the theology of Karl Barth. Eugene, OR: Wipf and Stock Publishers.

Mohammad, F. (1998). Ibn Khaldun's theory of social change: A comparision with Hegel, Marx and Durkheim. The American Journal of Islamic Social Sciences, 15(2), 25-46.

Mokyr, J. (2010). Entrepreneurship and the industrial revolution in Britain. In D. S. Landes, J. Mokyr, \& W. J. Baumol (Eds.), The invention of enterprise: entrepreneurship from ancient Mesopotamia to modern times (pp. 189-210). New Jersey, NJ: Princeton University Press. doi: https://doi.org/10.1515/9781400833580-011

Nadvi, M. A. B. (2005). Ma'ashiyat ka Islami falsafa (Economic Philosophy of Islam). Multan, Pakistan: Idara Talifat-e-Ashrafiya.

Polanyi, K. (1944). The great transformation: The political and economic origins of our time. Boston, MA: Beacon Press.

Portes, A. (1998). Social capital: Its origins and applications in modern sociology. Annual Review of Sociology, 24(1), 1-24. doi: https://doi.org/10.1146/annurev.soc.24.1.1

Raffaelli, T. (2003). Marshall's evolutionary economics. London, UK: Routledge. doi: https://doi.org/10.4324/9780203117286

Reisman, G. (1998). Capitalism. Illinois, IL: Jameson Books.

Rethel, L. (2011). Whose legitimacy? Islamic finance and the global financial order. Review of International Political Economy, 18(1), 75-98.

doi: https://doi.org/10.1080/09692290902983999

Schumacher, E. F. (1973). Small is beautiful: A study of economics as if people mattered. London, UK: Blond \& Briggs Ltd.

Seidl, D. (2007). General strategy concepts and the ecology of strategy discourses: A systemic-discursive perspective. Organization Studies, 28(2), 197-218. doi: https://doi.org/10.1177/0170840606067994

Siddiqi, M. N. (2011). Islamization of knowledge: Reflections on priorities. The American Journal of Islamic Social Sciences, 28(3), 15-34. doi: https://doi.org/10.35632/ajiss.v28i3.335

Suri, A. W. (2007). The possibility of meta-history. Market Forces, 2(1), 1-16.

Tainter, J. A. (1988). The collapse of complex societies. Cambridge, UK: Cambridge University Press.

Toffler, A. (1980). The third wave. New York, NY: Bantam Books. 
Walzer, M. (1983). Spheres of justice: A defence of pluralism and equality. New York, NY: Basic Books.

Wittgenstein, L. (1985). Philosophical investigation. Cambridge, UK: Cambridge University Press.

Woolcock, M. (1998). Social capital and economic development: Toward a theoretical synthesis and policy framework. Theory and Society, 27(2), 151-208. doi: https://doi.org/10.1023/A:1006884930135

Zaman, A. (2014). Islam versus economics. In M. K. Hassan, \& M. K. Lewis (Eds.), Handbook on Islam and economic life (pp. 45-70). Chaltenham, UK: Edward Elgar Publishing Limited. doi: https://doi.org/10.4337/9781783479825.00008

Zaman, A. (2016). What is Islamic economics? The Express Tribute. Retrieved from: https://tribune.com.pk/story/1029286/what-is-islamic-economics/ 